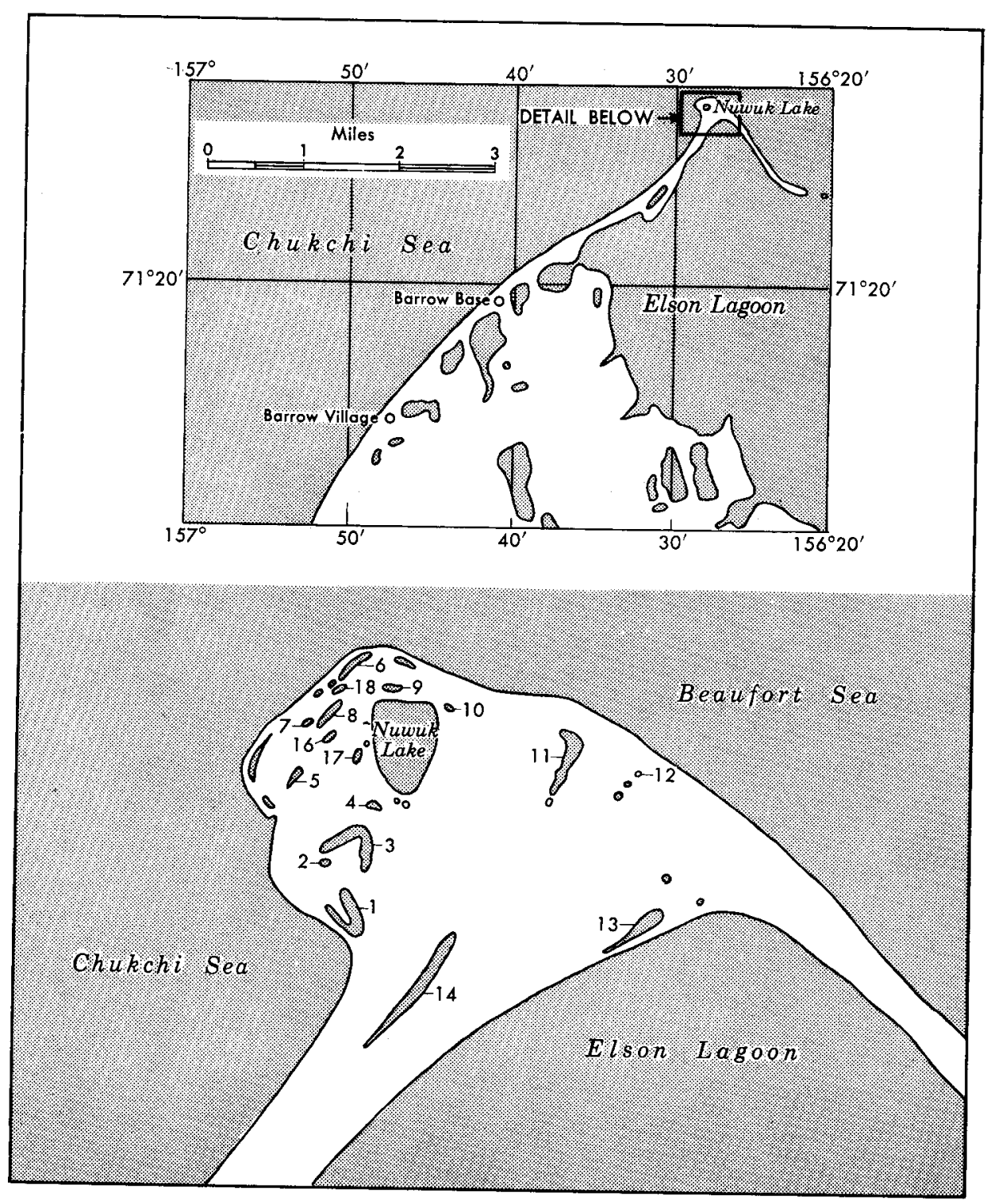

Fig. 1. Barrow Peninsula, Alaska sketched from photographs and showing the locations of the various bodies of water. 


\title{
THE MARINE NATURE OF NUWUK LAKE AND SMALL PONDS OF THE PENINSULA OF POINT BARROW ALASKA*
}

\author{
John L. Mohr** \\ Donald J. Reish $\dagger$ \\ J. Laurens Barnard $\uparrow \dagger$ \\ Roger W. Lewis*** \\ Stephen R. Geiger***
}

\begin{abstract}
Q INCE July 1952 when thousands of the amphipod Gammarus setosus $D$ were discovered in windrows along the northwest shore of Nuwuk Lake a study has been carried out on this halocline lake and the small ponds on the end of the peninsula of Point Barrow, Alaska.
\end{abstract}

\section{Physical and chemical characteristics of the small ponds}

Barrow peninsula extends as a narrow gravel spit running nearly northeastward from the mainland and ending at the north in an expanded area. The longitudinal axis of the peninsula roughly halves this distal expanded portion (Fig. 1). The higher southeast side is covered with tundra and the lower northwest side is composed primarily of sand and gravel with a few plants. A few ponds lie in the tundra, but there are more than twenty in the lower area. The shallow ponds on the tundra side having bottoms of black sulfide mud, lacked active macroscopic organisms in 1953 and were not studied thereafter.

Based on the stability of their basins two groups of ponds can be recognized on the sand and gravel side of the peninsula, a transient and a persistent group.

The transient ponds are formed by a seasonal reworking of the sand and gravel along the shore (Rex 1955, MacGinitie 1955). They are most

*These studies were aided by contracts between the Office of Naval Research, Department of the Navy and the University of Southern California, and between the senior author and the Arctic Institute of North America.

**Current address, Biology Department, University of Southern California, Los Angeles, California.

$\dagger$ Current address, Division of Biological Sciences, Long Beach State College, Long Beach, California. fornia.

††Current address, Beaudette Foundation for Biological Research, Solvang, Cali- 
commonly formed in areas between the constantly changing dike-like shingle bar, which is usually 3 to 5 feet high and 9 to 12 feet wide, and the lower-lying area behind it, which is several feet above sea-level (Fig. 2).

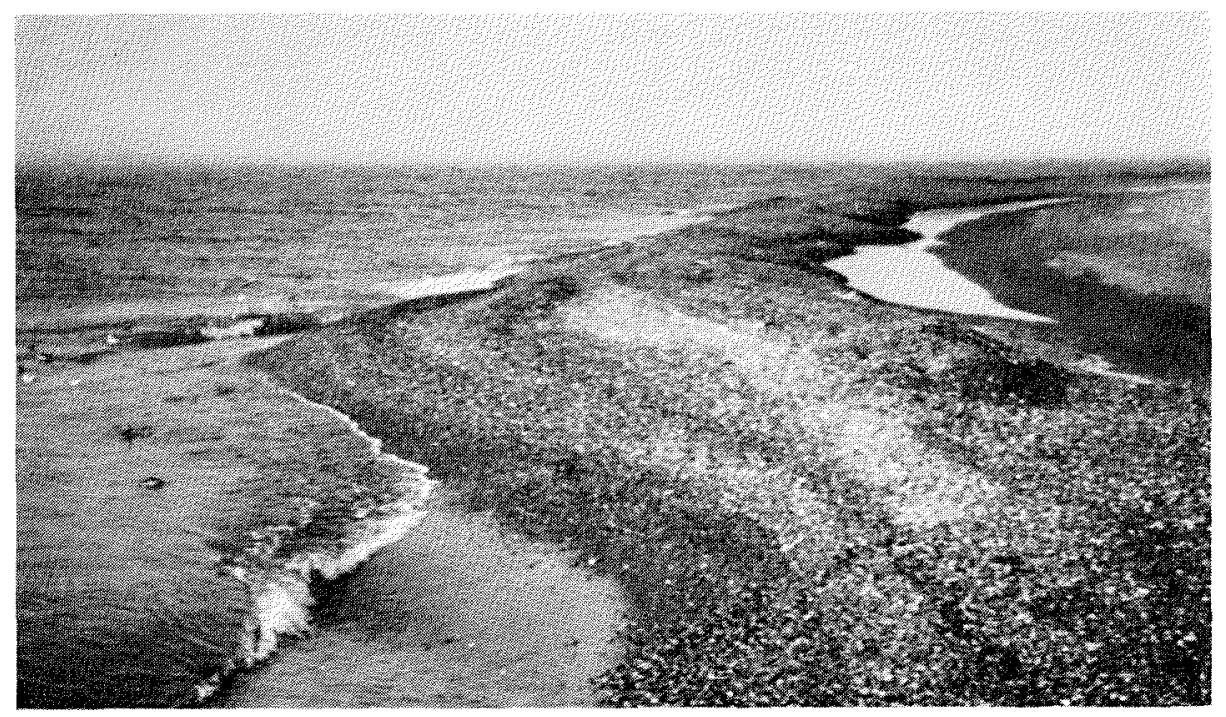

Fig. 2. Shingle bar at shore line showing a transient pond to the right.

The basins that contain the remaining ponds change more slowly. From 1952 to 1960 the alterations in the shape of the ponds in this group changed none of them beyond recognition. Their distance from shore protects them from modification by the sea-ice, which when carried by currents and winds can move a good distance on to the land. In the spring of 1960 Robert Lavenberg (pers. comm.) observed a 6-foot-high pressure ridge extending across the northwest corner of the peninsula. It was pushed to within 150 feet of the edge of Nuwuk Lake.

The amount of water in each pond differs yearly and seasonally. The amount present is a function of the quantity of water contributed by melting snow and ice, storm waves, and spray from the ocean, the height of frozen ground preventing percolation and loss by summer evaporation. Maximum depths on August 24, 1953 for 13 ponds ranged from 6 to 70 inches. Water level had risen sufficiently to make ponds $1,2,3$, and 4 confluent. At other times the water level has been reduced to the extent that some of the smaller ponds are completely dried up, and only their shallow basins remain. Some summers several small ponds are formed around the edge of Nuwuk Lake when parts of the lake pinch off as the water level of the lake recedes.

The salinity of the water in each pond varies according to the amount of marine and fresh-water that has been introduced. A series of surface salinities determined in 1953 shows the range that is found in these ponds 
Table 1. Salinities, in \%o, of the small ponds of Barrow Peninsula.

\begin{tabular}{ccccc}
\hline Pond Number & 3-4 July 53 & 9 July 53 & 13 July 53 & 27 July 53 \\
\hline 2 & NR & 3.5 & 4.0 & 4.0 \\
3 & 0.5 & 4.0 & 4.0 & 4.0 \\
4 & NR & 2.0 & 2.5 & 2.5 \\
5 & NR & 1.0 & 1.0 & 2.5 \\
6 & NR & 28.0 & 25.0 & 24.5 \\
7 & NR & NR & 1.5 & NR \\
8 & NR & 2.0 & 2.0 & 2.0 \\
9 & 6.0 & 6.5 & 6.5 & 7.0 \\
10 & 0.5 & 0.5 & 0.5 & NR \\
11 & 0.5 & NR & 1.0 & NR \\
12 & NR & NR & 2.5 & NR \\
13 & NR & NR & 3.0 & DO \\
14 & NR & NR & 1.0 & DO \\
18 & NR & NR & 11.5 & DO \\
19 & NR & 4.5 & &
\end{tabular}

NR - no reading

DO - dried out

(Table 1). The ponds nearest the ocean are the most saline whereas the more protected ponds are quite fresh.

A series of surface temperatures for the ponds is shown in Table 2. The individual temperatures are apparently a function of the amount of insolation, hence of season and cloud cover, of the albedo of the gravel, and of the depth of the pond. Those with less water and greater exposed surface area probably absorb more solar radiation. This heating effect is balanced by the cooling effect that results from underlying permafrost, evaporation, and wind.

Table 2. Temperatures, in ${ }^{\circ} \mathrm{C}$, of the small ponds of Barrow Peninsula.

\begin{tabular}{cccc}
\hline Pond Number & 9 July 53 & 13 July 53 & 27 July 53 \\
\hline 1 & 8.6 & 6.5 & 10.1 \\
2 & 9.9 & 6.6 & 10.7 \\
3 & 8.5 & 6.6 & 9.8 \\
4 & 9.4 & 6.8 & 11.1 \\
5 & 11.3 & 7.5 & 12.1 \\
6 & 8.5 & 6.0 & 10.9 \\
7 & NR & 8.0 & NR \\
8 & 8.7 & 7.1 & 10.1 \\
9 & 8.2 & 7.0 & 9.9 \\
10 & 10.4 & 7.1 & 11.4 \\
11 & NR & 6.6 & NR \\
12 & NR & 6.9 & NR \\
13 & NR & 6.8 & NR \\
14 & NR & 6.9 & DO \\
18 & NR & NR & DO \\
\hline
\end{tabular}

NR - no reading

DO - dried out

\section{Biotas of the small ponds}

As is to be expected, the biotas of the ponds are affected by the latitude and by the proportion of marine and fresh-water. The macroscopic animals 
found in the temporary shoreline ponds are a chance assortment of the marine invertebrates familiar in the Barrow area: usually only a few amphipods, but after severe storms sponges, hydroids, soft corals, bryozoans and isopods. Most of these quickly die in the markedly changed environment (extremes of light and heat, change of salinity, and lack of food). The more permanent ponds contain species normally found in fresh or slightly brackish water of this area. Included in this assemblage are copepods, which are being studied with those of Nuwuk Lake by Mrs. Mildred S. Wilson of Anchorage, Alaska, a fairy shrimp (Eubranchinecta glacialis), and an oligochaete (Lumbriculus, or a related genus). The clam shrimp, (Lepidurus arctica) and ostracods that are often present in the numerous pools of the mainland and the base of the peninsula have not been found in any of the ponds in other parts of the peninsula. Algae, occasionally abundant enough to colour the water opaquely green, were present in several pools, but were not studied.

\section{Physical and chemical characteristics of Nuwuk Lake}

In Nuwuk Lake, the largest body of water on the peninsula, a particular combination of physical and chemical properties has allowed the establishment of a restricted but balanced marine biota.

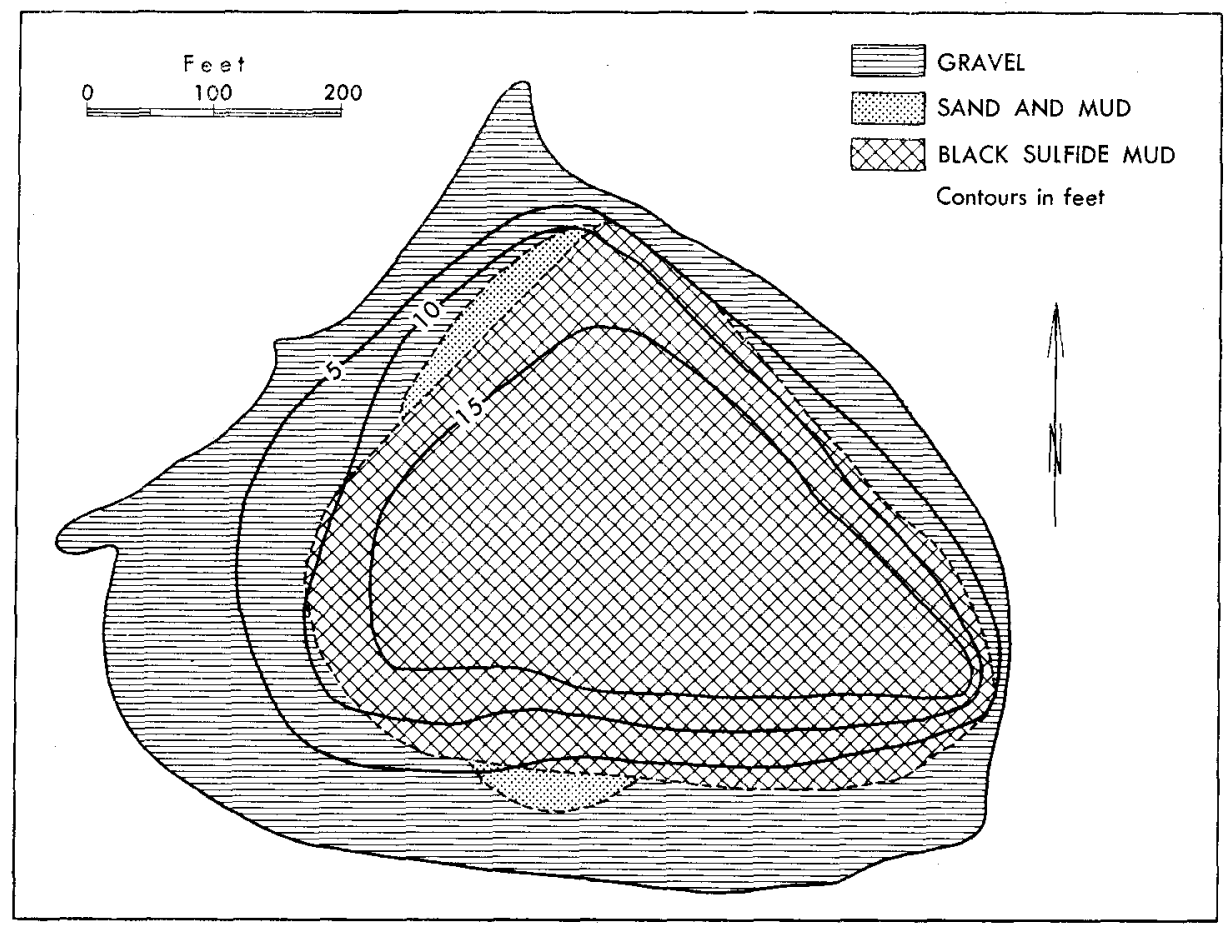

Fig. 3. Nuwuk Lake with substrata and depth contours. 
The greatest length of this lake is about 600 feet (Fig: 3) but this varies with the amount of water in the lake. The bottom slopes gently from the north and northwest and more steeply from the south and southeast to an eccentric deeper pool. A maximum depth of 18.5 feet was recorded when the basin was quite full. The edge of the lake is composed of a pebbly zone of varying width. Beginning at about the 7-foot depth, particularly on the gently sloping northwest bottom area, the pebbly zone is progressively replaced by yellowish brown sandy mud. Under this sandy mud a layer of fine black sulfide mud appears. Gradually the surface layer becomes thinner until it is only a few millimetres thick in the deepest part of the lake. As this layer diminishes the underlying black sulfide mud increases until it reaches a thickness of several feet. The black sulfide mud layer contains fragments of disintegrated tundra vegetation and is probably mainly a breakdown product of material that has sloughed into the lake since its formation.

Based on observations of MacGinitie (1955), former Director, and Max C. Brewer (pers. comm.), present Director of the Arctic Research Laboratory at Barrow, the following hypothesis is presented to explain the formation of this lake. The clockwise surface currents of the Beaufort Sea and the counterclockwise surface currents of the Chukchi Sea flowing from the direction of the Bering Sea converge at the peninsula. These currents deposited gravel and finer sediments in such a pattern that long fingers of sediments have been laid down forming a bay. (Such a pattern is now seen at many places along the arctic coast, as at the end of Tapkaluk Island to the east and alongside Peard Bay to the west.) This deposition continued until a barrier finally separated a lake from the sea - a lake whose bottom roughly corresponded to that of the adjacent sea. This barrier is now about 150 feet wide on the north edge of the lake. When an analysis of the sediments and Foraminifera from cores is completed (by Gordon Anderson, formerly of the Department of Geology of the University of Southern California) it is hoped that a better understanding of the origin of this lake will be possible.

Salinity determinations were made while the lake was frozen (1957 and 1960) and when it was free of ice (1953, 1954, and 1960). These measurements show a sharp and persistent halocline (a rapid change of salinity in a small change of depth) at between 5 and 6 feet. The halocline separates an essentially fresh surface layer from a hyperhaline deeper layer.

During the time that the lake is frozen the ice corresponds to the freshwater layer. The freshness of this ice is enhanced by the normal desalting process that is associated with freezing (Adams et al. 1960). Measurements are summarized in Fig. 4. The location of the halocline under the ice-cover, at least in late winter, corresponds to the ice-water interface.

When the lake is free of ice the halocline occurs between the 3- and 8-foot levels, the actual depth varying from year to year (Fig. 5). The lower layer has a salinity much above that of the adjacent arctic seas. The salinity increases gradually toward the bottom of the lake. 
Fresh-water often forms a layer over salt water when circulation is slight. This phenomenon is not restricted to Nuwuk Lake, but is found in larger enclosed bodies of water, e.g. Mogilnoje on Kildin Island of the Murman Coast and Saels $\phi$ (Seal Lake) in northeast Greenland, and characteristically is seen on the sea after the melting of the ice in summer. It is frequently seen in holes made through sea-ice where the interface may be so sharp that it produces strong refraction or carries a layer of particles floating on the surface of the sea-water. This layering has been excellently recorded by Kusunoki (1960) and Muguruma (1960, unpublished) from their work on the pack ice at the edge of Drift Station Bravo (Fig. 6), and is described in general terms by Nansen (1897) and Calvert (1960) based on observations made during their arctic explorations. In the Arctic Ocean the layers are thicker, but differences are less. The lower levels of this ocean seldom exceed $35 \%$ salinity as compared to about $60 \%$ salinity in Nuwuk Lake. However, the similarities in dynamic hydrography of these bodies of water are unmistakable, their great difference in size notwithstanding.

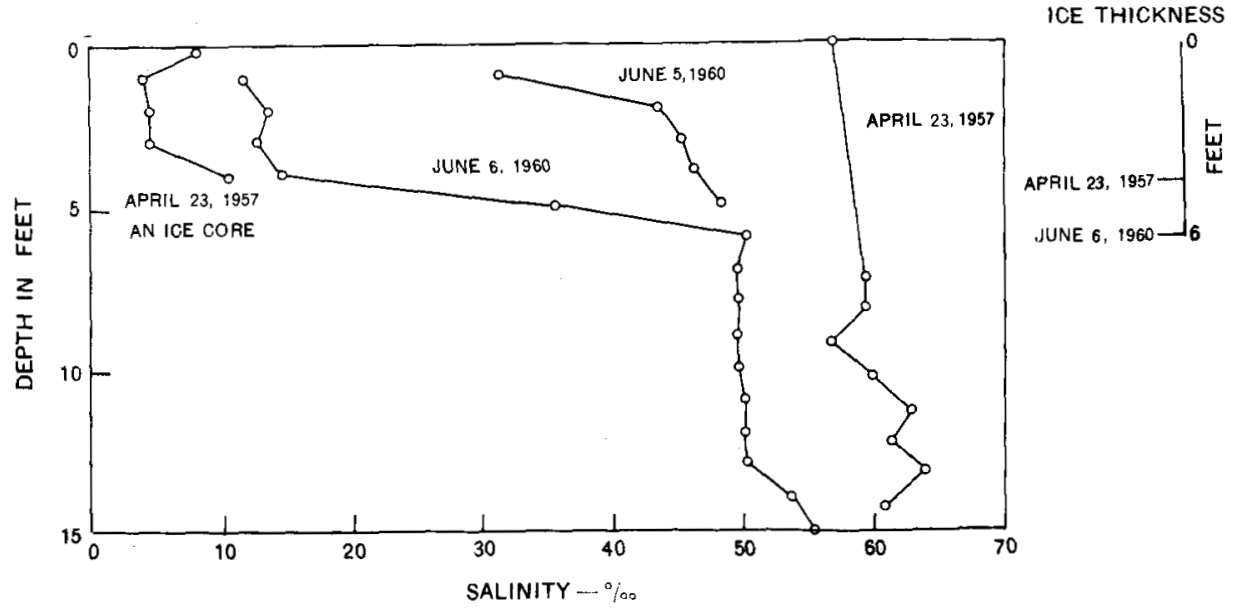

Fig. 4. Salinity of Nuwuk Lake when ice-covered. Curve farthest to left is that of a core of ice. In a recently constructed hole (June 2,1960 ) a halocline rapidly develops (samples taken June 5 and 6,1960 ) as the upwelling saline layer balances the runoff of fresh water from melting.

From the densities of water in Nuwuk Lake a curve similar to that plotted for salinity may be derived. This shows a ten-fold increase from about 3 to about 30 across the halocline. With such an extreme change in density, it is not surprising to find quite stable layering, even in the presence of summer winds that had an average velocity for July and August of $\mathbf{1 1 . 8}$ and 12.7 m.p.h., respectively, at Barrow (Wiggins and Thomas, in press). 
Fig. 5. Salinity of Nuwuk Lake when ice-free.

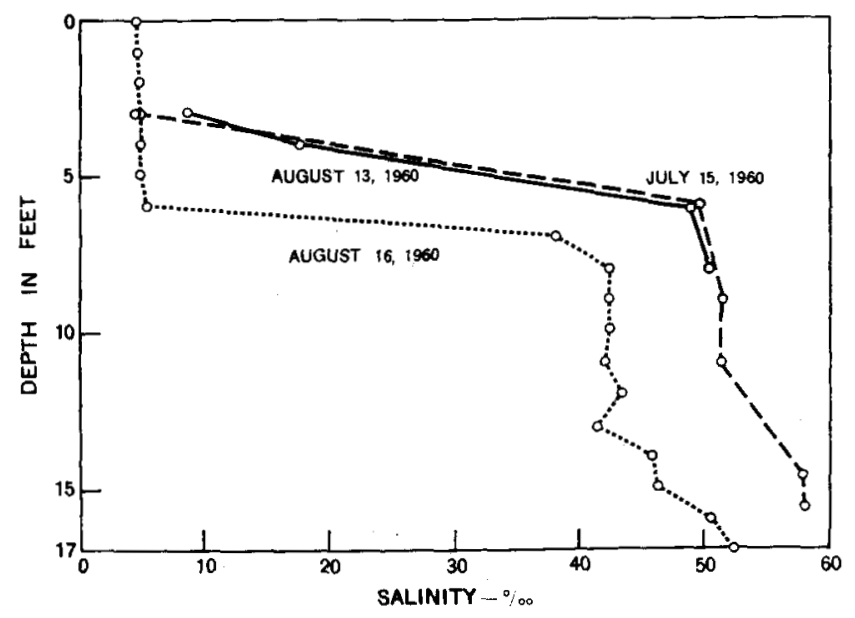

Undoubtedly some diffusion does occur between these layers, but has not been sufficient in the period of our observation to eliminate the halocline during the ice-free season. The annual freezing is a necessary part of maintaining the separation of the layers. The ice serves to protect the lake from wind mixing, but what is more important, it re-establishes each year a freshwater layer 5 to 6 feet in depth. Whatever salt diffuses into the upper layer from the lower levels during summer moves downward through the ice during the winter so that all of it has been added to the saline layer by the time melting is completed.

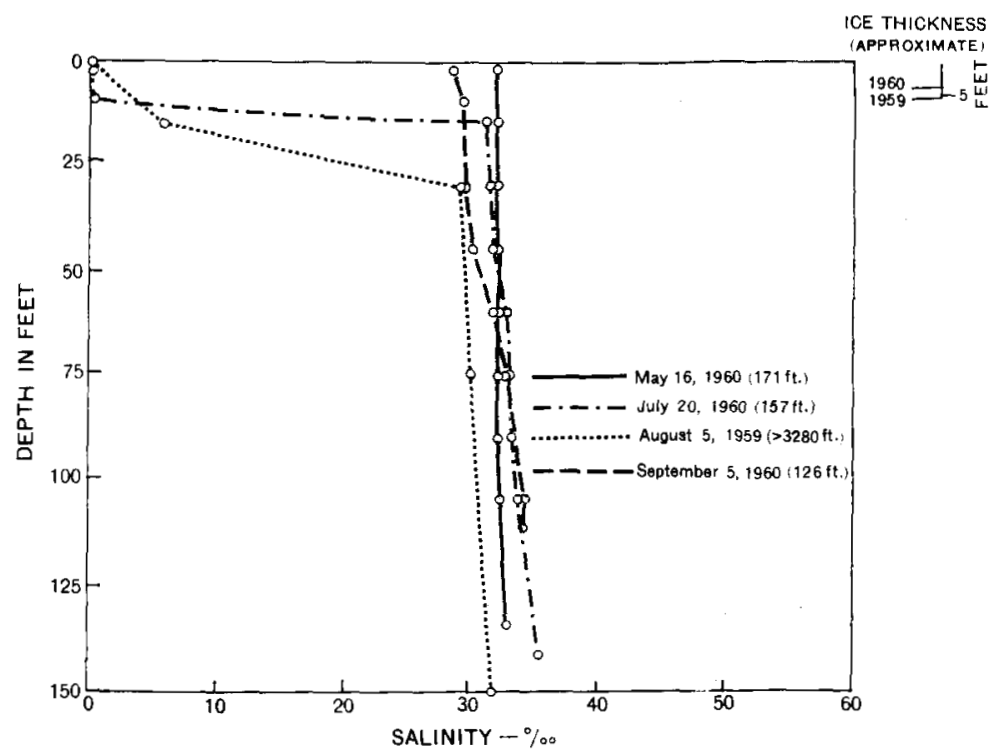

Fig. 6. Salinity, as recorded from Drift Station Bravo (Ice Island T-3) as it drifted between $71^{\circ}$ and $72^{\circ} \mathrm{N}$ latitude from north of Mackenzie River to northwest of Point Barrow. Numbers in parentheses indicate depth to bottom. 
A persistent halocline does not exist in any of the small ponds although the salting out process does operate in at least one of these. In Pond 1, which has a depth of about 70 inches and is the deepest of this group, a salinity profile of $14.0 \%, 18.5 \%$, and $21.5 \%$ was recorded at $1.5-, 3-$, and 5 -foot depths, respectively. This is a notable gradient, though a separation of layers does not persist. Shallowness and lack of protection from wind and storm waves insure mixing.

A complete set of temperature readings from Nuwuk Lake is not available. Therefore, we do not wish to report at this time more than that the temperature of the lake is close to that of the adjacent ocean as recorded by Johnson (1956).

Even with the apparently non-circulating bottom layer the amount of dissolved oxygen in a period in which the lake is frozen (Fig. 7) compares favorably with the 5 to $10 \mathrm{ml} . / 1$. of the Arctic Ocean (Kusunoki 1960 and Muguruma, unpublished). It is presumed that the conditions governing levels of dissolved oxygen of Nuwuk Lake aproximate those of other hyperhaline bodies of water (Sverdrup et al. 1942, Emery and Stevenson 1959). In ice-free seasons oxygen is apparently supplied to the deeper layer during storms by waves that break across the north and northwest shore of the lake. Oxygen thus introduced, dissolved in the denser sea-water, easily passes through the less dense and circulating freshwater layer. It continues downward due to the greater density of the water. Perhaps addi-. tional oxygen from the green plants that are present is picked up. The quantity of oxygen at any level is reduced by the metabolism of the oxygenconsuming organisms in the lake. Over the area of the sulfide mud further amounts of oxygen are presumably removed by the formation of sulfite and sulfate.

\section{Marine biota of Nuwuk Lake}

The hydrological conditions discussed above permit the existence of a persistent marine biota. This has been established by the repeated finding, when collecting techniques were closely duplicated, of the same species (Table 3), including young stages explainable only by the presence of reproducing populations. The macroscopic animals are all rather common representatives of the shallow-water fauna of the Barrow area, though certain major groups, such as sponges, coelenterates, and echinoderms, are absent.

Associated with the bottom are turbellarians, nematodes, ostracods, copepods, priapulids, nemerteans, and molluscs. Oligochaetes are well represented in the gravelly bottom, but poorly so in the sandy mud, where a more complex fauna exists.

The animals that move freely and widely and have quite wide salinity tolerances are the most conspicuous component (Mohr 1953). These are gammaridean amphipods, Gammarus setosus and Pseudalibrotus birulai (the latter assigned incorrectly to the related genus Onisimus in Mohr, 1953). In the summer of 1953 more than 5000 Gammarus and about 2500 
Pseudalibrotus were trapped. Some thousands more were netted from the shallow waters at the northwest corner. Here the Gammarus to Pseudalibrotus ratio was more than ten to one. In 1960 the amphipod population was much reduced and the ratio reversed, the Pseudalibrotus clearly being the predominant amphipod in the lake.

Sculpins (Myoxocephalus scorpius, $M$. verrucosus auct.) have always been inconspicuous. Adults were seen only in July 1952, when we observed three at one time and when $\mathrm{Mr}$. Adair Fehlmann netted one while working from an ice cake floating in the lake. An egg mass was collected on August 19, 1953. Young were observed several times and 26 were taken by hand net or in a small epibenthic dredge in 1954. A number of sculpins were observed in 1960, particularly in the small pools pinched off from the south end of the lake. A few were collected to check their identity and the remainder returned to the lake.

Fig. 7. Dispersion of dissolved oxygen in Nuwuk Lake.

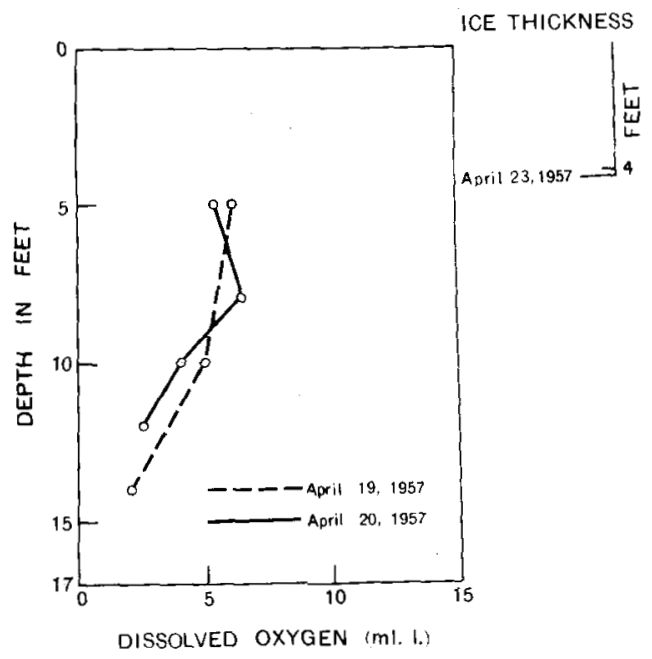

Of the other organisms of the lake our knowledge is so limited as to permit few generalizations. Mysis thrives in the "sea-water" layer. It has been identified by Dr. Charlotte Holmquist (who has examined our material and has herself taken many specimens from Nuwuk Lake) as Mysis relicta, which occurs commonly in the immediately adjacent seas as well as in Elson Lagoon (Fig. 1). In fact Holmquist (pers. comm.) has noted that quite distinct $M$. relicta and $M$. oculata occur in the offshore waters. There is thus no reason to assume that the population is an environmentally modified Mysis oculata.

Mrs. Mildred S. Wilson (pers. comm.) describes the planktonic copepods as common euryhaline arctic species.

Much of the sampling of the bottom invertebrates has been done with devices that do not permit determination of point of origin. Thus although we believe that the polychaetes, molluscs, priapulids, and nemerteans are 
both solitary and few, we know too little of their occurrence to state this firmly. The foraminiferans, turbellarians, nematodes, ostracods and harpacticoid copepods are all common bottom forms where "sea-water" overlies the bottom.

The algae so far taken occur sparsely and provide a very limited photosynthetic base for the energy requirements of the fauna. There are occasional small accumulations of filamentous forms downwind in shallow parts of the lake. Diatoms have been common, but never abundant in bottom samples with the foraminiferans, ostracods, and similar forms.

\section{Nuwuk Lake compared with other halocline lakes}

So far few arctic or subarctic halocline lakes have been reported. The best known example is "die berühmte Reliktsee" Mogilnoje. Derjugin (1928) has given a comprehensive account of the work done there. Mogilnoje Lake is located on Kildin Island off the Murman coast at $67^{\circ} 40^{\prime} \mathrm{N}$. and $34^{\circ} 20^{\prime} \mathrm{E}$. It is larger and deeper than Nuwuk Lake with a halocline below 30 feet ("a very steep gradient between five and six fathoms") and below 42 feet a sulfide ("stinkendes Wasser", Knipowitsch 1895) zone. In the surface zone, to a depth of 3 or 3.5 fathoms, are freshwater copepods and a "Gammarus locusta", which could be any of several species according to current usage and may well be G. setosus. The great depth of the freshwater layer, which is several times that of maximum ice thickness under present climatic conditions, permits the persistence of freshwater organisms. This is not so in Nuwuk Lake where freezing to or almost to the halocline combined with periodic brackishness in the mixolimnion (epilimnion) prevents the survival of any true freshwater organisms. In the middle zone of Mogilnoje Lake there are brown algae and a considerably wider range of macroscopic marine bottom invertebrates than occurs in Nuwuk Lake. The Russian biologists did not report and perhaps did not look for an interstitial fauna (meso- or micro-fauna). Two ecological groupings were recognized among the marine bottom invertebrates, a littoral or sublittoral and a quasi-estuarine group, the latter being considerably richer in species. An indigenous cod and a flounder were reported. The deep sulfide zone is azoic.

The manner of formation of Mogilnoje Lake is not explained, but the photographs in Derjugin (1928) appear to show the separation of lake and sea by a gravel bar similar to that at Nuwuk Lake. It appears to us that the mechanisms operating at Mogilnoje Lake may be similar to those at Nuwuk Lake. Derjugin mentions the existence in Novaya Zemlya of relict lakes similar to Mogilnoje Lake and there are photographs of some of these in the review cited, but no useful accounts.

Another halocline lake, Saels $\phi$, formed from an old fiord has been described by Johansen (1911) and Trolle (1913). This 25-mile-long by 2 -mile-wide lake runs along the 77th parallel. It is now cut off from the sea by a clay and gravel deposit and is several miles inland. Melt-water from a 
Table 3. Organisms collected from Nuwuk Lake in 1952-60.

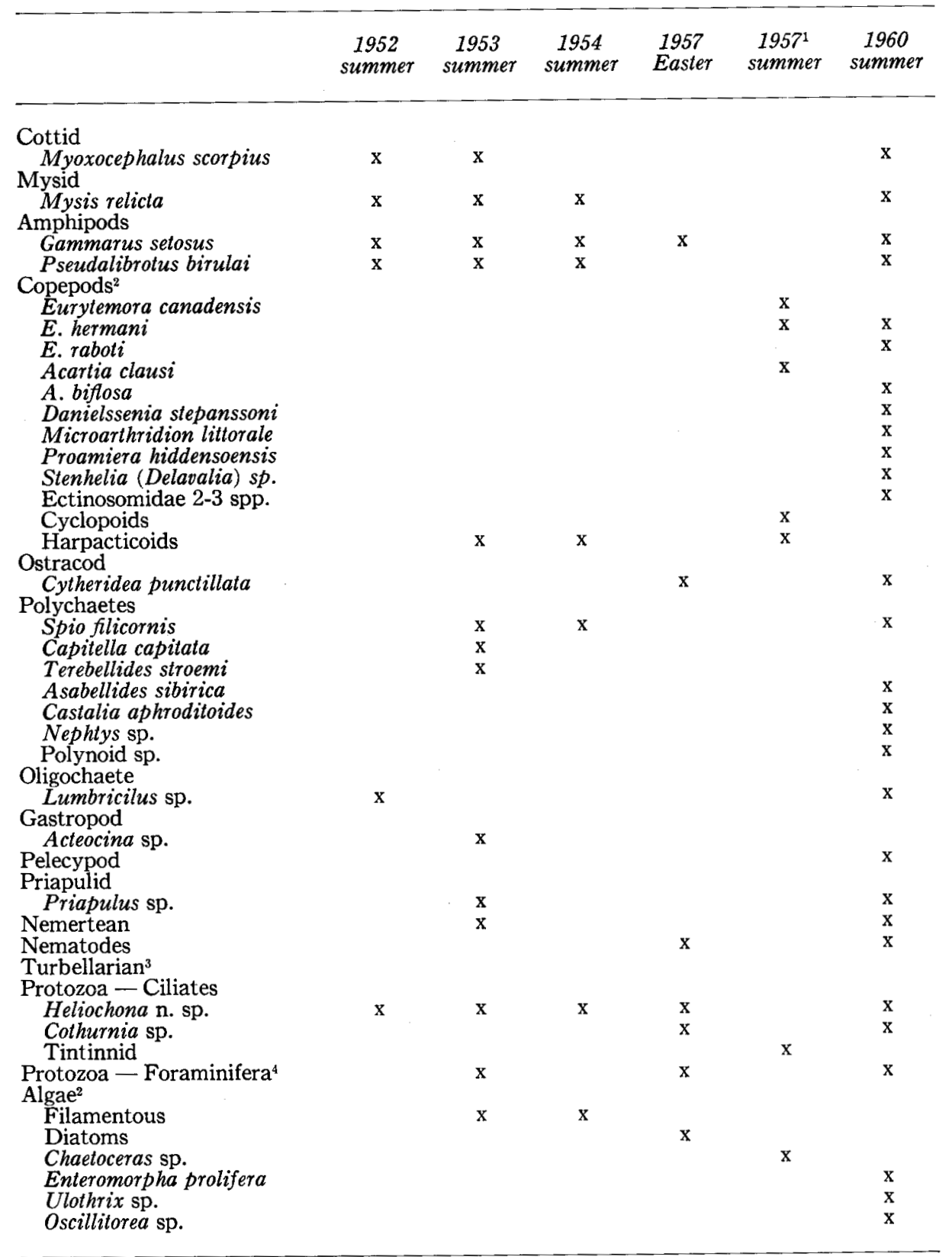

1 Based on collections with a plankton net (Johnson 1958).

2 Plankton nets were not used extensively in the program until the summer of 1957.

3 Taken in 1961, apparently not uncommon.

4 Living Foraminifera were noted first by Prof. Warren Mateer (Colo. School of Mines) in 1953 and were taken again by Dr.\& Mrs. G. Dallas Hanna in 1957. Arenaceous forms predominate in our collections, which are under study by $\mathrm{Mr}$. Gordon Anderson (see page 215). 
great ice sheet to the west provides a deep freshwater surface layer. A sharp halocline occurs at "precisely" 56.75 metres. Below this there is a deep monimolimnion that becomes azoic at 70 metres. Unfortunately, other than reference to seals for which the lake was named, there is no mention of organisms from Saels $\phi$, although it would appear that, as in Mogilnoje Lake, freshwater organisms might live above the halocline and marine organisms between the freshwater and azoic layers (here from 50 to 70 metres).

Two Norwegian lakes, both isolated fiords, deserve mention. Dahl (1946) reports briefly a marine fauna in Rossfjordvatn near Troms $\phi$. Although this lake (pers. comm.) has characteristics comparable with those of Nuwuk and Mogilnoje lakes, sufficient information is not available for a detailed comparison. Strøm $(1955,1957)$ has published a preliminary ac-

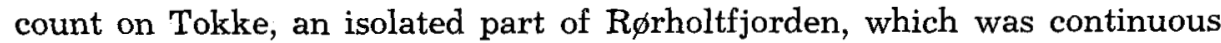
with the sea some thousands of years ago when the sea-level was higher, but now lies well above sea-level. Strøm has so far given no data on biota.

All these lakes appear to escape wind-churning because an ice-cover and their size and shape protect them. In all of them the greater density in the deeper layers tends to maintain the deep layer. The adding of sea-water by occasional great storms is not reported for these arctic lakes, but a classical example in the temperate zone is that of Hemmelsdorfersee near Lübeck (Griesel 1935), which twice in a century received large quantities of sea-water during major storms.

It may be concluded that although relatively few examples have been reported, conditions for halocline lakes, with a balanced biota, are likely to exist in many places along the arctic and adjacent seas and discovery of more of them may be expected.

\section{References}

Adams, M. C. Jr., D. N. French, and W. D. Kingery. 1960. Solidification of sea ice. J. Glaciol. 3:745-61.

Barnard, J. L. 1959. Epipelagic and under-ice Amphipoda of the central arctic basin. In V. Bushnell edit. USAF Camb. Res. Cent., Geophys. Res. Pap. No. 63, 1:115-52.

Calvert, J. 1960. Surface at the Pole, the extraordinary voyage of the USS Skate. New York: McGraw-Hill Book Co. Inc. 220 pp.

Dahl, E. 1946. Zoologiska intryck från en vår i Nordnorge. Fauna och Flora Popular Tidskrift för Biologi, 1946:256-82.

Derjugin, K. M. 1928. Der Reliktensee Mogilnoje (Insel Kildin im Barents-Meer). Fauna Arktika, 5:491-560.

Emery, K. O., and R. E. Stevenson. 1957. Estuaries and lagoons, I. Physical and chemical characteristics. In J. W. Hedgpeth, edit. Treatise on Marine Ecology and Paleoecology. Geol. Soc. Am. Mem. 67, 1: 673-93.

Griesel, R. 1935. Die Aussüssung des Hemmelsdorfer Sees. Mitt. Geogr. Ges. Lübeck, 2. Reihe, 38:77-83.

Johansen, F. 1911. Danmark-Ekspeditionen til Grønlands Nordøstkyst 1906-1908 under ledelse af L. Mylius-Erichsen Bind V, Freshwater life in North East Greenland. Medd. om Grønl., 45:319-37. 
Johnson, M. W. 1956. The plankton of the Beaufort and Chukchi Sea areas of the Arctic and its relation to the hydrography. Arct. Inst. N. Am. Tech. Pap. No. 1, 32 pp. 1958. Observations on inshore plankton collected during summer 1957 at Point Barrow, Alaska. J. Marine Res. 17:272-81.

Knipowitsch, N. 1895. Ueber den Reliktensee "Mogilnoje" auf der Insel Kildin an der Murman-Küste. Izv. Imp. Akad. Nauk, 5:459-73.

Kusunoki, K. 1960. Oceanographic observations on ice island T-3 in the summer of 1959. Arct. Inst. N. Am. Sci. Rep. No. 5, 18 pp.

MacGinitie, G. E. 1955. Distribution and ecology of the marine invertebrates of Point Barrow, Alaska. Smithson. Misc. Coll. Vol. 128, No. 9, Pub. 4221, iv +201 pp.

Mohr, J. L. 1953. Some observations on arctic crustaceans and their associates: Notes on the fauna of Nuwuk Pond, Point Barrow. Stanf. Univ. Publ. Univ. Ser. Biol. Sci. 11: 14-18.

Nansen, F. 1897. Farthest North. New York: Harper and Brothers Publishers. 2 Vols., 587 and $729 \mathrm{pp}$.

Rex, R. W. 1955. Microrelief produced by sea ice grounding in the Chukchi Sea near Barrow, Alaska. Arctic 8:177-86.

Strøm, K. M. 1955. Waters and sediments in the deep of lakes. Mem. Inst. Ital. Idrobiol. de Marchi, Supp. 8:345-56.

1957. A lake with trapped sea water? Nature 180:982-3.

Sverdrup, H. U., M. W. Johnson, and R. H. Fleming. 1942. The Oceans. New York: Prentice-Hall, $1087 \mathrm{pp}$.

Trolle, A. 1913. Danmark-Ekspeditionen til Grønlands Nordøstkyst 1906-1908 under ledelse af L. Mylius-Ericksen. Bind I, II. Hydrographical observations for the Danmark Expedition. Medd. om Grønl, 41:271-426.

Wiggins, Ira L., and J. H. Thomas. A flora of the Alaskan Arctic Slope. In press. 
Johnson, M. W. 1956. The plankton of the Beaufort and Chukchi Sea areas of the Arctic and its relation to the hydrography. Arct. Inst. N. Am. Tech. Pap. No. 1, 32 pp. 1958. Observations on inshore plankton collected during summer 1957 at Point Barrow, Alaska. J. Marine Res. 17:272-81.

Knipowitsch, N. 1895. Ueber den Reliktensee "Mogilnoje" auf der Insel Kildin an der Murman-Küste. Izv. Imp. Akad. Nauk, 5:459-73.

Kusunoki, K. 1960. Oceanographic observations on ice island T-3 in the summer of 1959. Arct. Inst. N. Am. Sci. Rep. No. 5, 18 pp.

MacGinitie, G. E. 1955. Distribution and ecology of the marine invertebrates of Point Barrow, Alaska. Smithson. Misc. Coll. Vol. 128, No. 9, Pub. 4221, iv + 201 pp.

Mohr, J. L. 1953. Some observations on arctic crustaceans and their associates: Notes on the fauna of Nuwuk Pond, Point Barrow. Stanf. Univ. Publ. Univ. Ser. Biol. Sci. 11: 14-18.

Nansen, F. 1897. Farthest North. New York: Harper and Brothers Publishers, 2 Vols., 587 and $729 \mathrm{pp}$.

Rex, R. W. 1955. Microrelief produced by sea ice grounding in the Chukchi Sea near Barrow, Alaska. Arctic 8:177-86.

Strøm, K. M. 1955. Waters and sediments in the deep of lakes. Mem. Inst. Ital. Idrobiol. de Marchi, Supp. 8:345-56.

1957. A lake with trapped sea water? Nature 180:982-3.

Sverdrup, H. U., M. W. Johnson, and R. H. Fleming. 1942. The Oceans. New York: Prentice-Hall, 1087 pp.

Trolle, A. 1913. Danmark-Ekspeditionen til Grønlands Nord $\varnothing$ stkyst 1906-1908 under ledelse af L. Mylius-Ericksen. Bind I, II. Hydrographical observations for the Danmark Expedition. Medd. om Grønl, 41:271-426.

Wiggins, Ira L., and J. H. Thomas. A flora of the Alaskan Arctic Slope. In press. 